\title{
Impact of Frontline Demonstrations on Yield of Soybean (Glycine max L. Merril) under Rainfed Conditions in Uttarakhand, India
}

\author{
S.B. Singh* \\ KVK, Jakhdhar, Rudraprayag, G.B.P.U.A. \&T., Pantnagar, India \\ *Corresponding author
}

Keywords

Economics, Extension gap, FLD, Technology gap, Technology index, Soybean yield

Article Info

Accepted:

10 April 2018

Available Online:

10 May 2018

\section{A B S T R A C T}

The study was carried out by Krishi Vigyan Kendra, Jakhdhar, Rudraprayag to know the yield gaps between improved package and practices under front line demonstration (FLD) and farmer's practice (FP) of Soybean crop under rainfed conditions. Front line demonstrations (FLDs) were conducted on 30 farmer's fields each year to demonstrate the impact of improved agro-techniques on production and economic benefits under rainfed conditions of Uttarakhand in Central Himalayan Region during kharif seasons of two consecutive years i.e. 2011 and 2012. The technologies demonstrated in FLDs recorded additional yield over farmer's practice. Under FLDs the grain yield of Soybean was increased by 30.96 per cent over FP. The extension gap, technology gap and technology index were calculated as $3.77 \mathrm{q} / \mathrm{ha}, 14.06 \mathrm{q} / \mathrm{ha}$ and 46.86 per cent, respectively. Adoption of improved package of practices in Soybean cultivation recorded higher B: C ratio (1.89) as compared to FP (1.53). Yield enhancement and higher net returns observed under FLDs of improved technologies in soybean. Thus, the productivity of Soybean could be increased with the adoption of recommended improved package of practices. The study resulted to convincing the farming community for higher productivity and returns.

\section{Introduction}

Soybean (Glycine $\max \quad$ L. Merril) is recognized as golden or miracle bean due to its high nutritive value and various usage viz., for feed, oil and soy food products. It is rich in protein (38-42\%) and contains 18 - 22 per cent edible oil. Soybean ranked first in the world in oil production $(57 \%)$ and in the international trade markets (Meena et al., 2012). Soybean continues to be number one oilseed crop in India occupying 11.67 million ha area with production of 8.59 million tonnes and productivity $737 \mathrm{Kg} / \mathrm{ha}$ (GOI, 2016). As an exceptional crop among oilseeds, soybean attained an unparallel glory of its horizontal expansion in very short span of nearly four decades (Dupare et al., 2012). The adoption of recommended production technology among farmers is not very encouraging. The reason may be that either the promising technologies have not yet reached the farmer's fields or farmers are unable to use improved technology due to various socio-economic reasons. Hence, an efficient technology transfer system is advocated and conducting frontline demonstration on farmer fields have proved as an effective means for creating 
awareness and acceptance of improved technologies. Keeping this in view, the present study was carried out to find out the effect of technological interventions on soybean productivity and economics.

Soybean is grown mostly in hills of Uttarakhand state and has become an integral part of the diet owing to its nutritional quality and consumed in various forms. There is no scope for area expansion in near future; additional production could be harvested by increasing the productivity per unit area (Nagarajan, 1997). Soybean production has to be increased by adopting improved production practices. There are several constraints of low productivity of Soybean in India, out of which poor extension of improved agronomic practices is on the top. Moreover, poor agronomic practices such as higher seed rate, unsuitable varieties, faulty nutrient management as well as Negligence of plant protection measures of crop from insect-pest and wild animals are also responsible for low productivity of Soybean. Frontline demonstration is the modern concept with the objective to demonstrate newly released crop production and protection technologies and its management practices at farmer's fields under different farming situations. While demonstrating the technologies in the farmer's fields, the scientists are required to study the various factors contributing higher crop yield, constraints in field production and thereby generate production data and feedback information. Keeping these in view, FLDs of improved production technology on Soybean were conducted to enhance the productivity and economic returns and also convincing the farmers for adoption of improved production technologies in soybean crop.

\section{Materials and Methods}

Front-line demonstration with improved package of practices on Soybean were conducted at thirty farmer's fields during kharif season of two consecutive years of 2011 and 2012 in different villages i.e. Tuneta, Devshal, Bainoli, Mudishera, Patuli, Narayankoti, Sankari, Tyuri, Bansu, Kuthera and Jakhdhar of Rudraprayag district (Uttarakhand). The soils of the farmer fields were Sandy-loam in texture and medium to low in NPK. Each demonstration was conducted on an area of 0.02 ha. FLD plots were kept for assigning farmers practices. Prior to conducting FLDs, group meeting and specific skill training was given to the selected farmers regarding package of practices of Soybean crop.

To popularize the improved Soybean agrotechniques for enhancing the production, constraints in soybean production were identified though participatory approach. Preferential ranking technique was utilized to identify the constraints faced by the respondent farmers in soybean production. Farmers were also asked to rank the constraints they perceive as limiting factor for soybean cultivation in order of preference. Based on top rank of farmer's problems identified, front line demonstrations were planned and conducted at the farmer's fields. The improved agro-techniques selected for FLDs given in Table 1. The Soybean crop was sown at $30 \mathrm{~cm}$ (row-row) apart in line using seed rate of $75 \mathrm{~kg} / \mathrm{ha}$ in month of May and June during both the years. The average yield of FLD and farmer practice has been taken in both the years for interpretation of the results. The extension gap, technology gap and technology index were calculated using the following formula as suggested by Samui et al., (2000).

Extension gap $(\mathrm{q} / \mathrm{ha})=$ Demonstration yield $(q / h a)$ - Yield of local check (q/ha).

Technology gap $(\mathrm{q} / \mathrm{ha})=$ Potential yield $(\mathrm{q} / \mathrm{ha})$ - Demonstration yield (q/ha). 
Technology index $(\%)=[($ Potential yield Demonstration yield) / Potential yield] x 100

The satisfaction level of participating farmers for the performance of improve demonstrated technology was also assessed.

Total 30 farmers each year were selected to measure satisfaction level for the performance of improved technology.

The selected respondents were interviewed personally with the help of a pre-tested and well-structured interview schedule. Client Satisfaction Index was calculated as below.

Client satisfaction index $=$ (Individual score obtained/ Maximum score possible) x 100.

The data on yield were recorded and analysed for interpretation of the results.

The economic-parameters (gross return, net return and $\mathrm{B}$ : $\mathrm{C}$ ratio) were worked out on the basis of prevailing market prices of inputs and minimum support prices of outputs.

\section{Results and Discussion}

\section{Constraints in soybean production}

Problems faced by the farmers in Soybean cultivation were documented during the study. Perusal of the data from Table 2 indicated that non-availability of improved varieties of Soybean $(80 \%)$ was given the top most rank followed by low technical knowledge (73\%), incidence of insect (67\%), damage caused by wild animals $(63 \%)$, use of higher seed rate $(30 \%)$, low fertility status $(27 \%)$, weed infestation $(25 \%)$ and diseases $(13 \%)$ were the major constraints to soybean cultivation.

Dhruw et al., (2012), Meena et al., (2014) and Singh et al., (2014) have also reported similar constraints.

\section{Soybean yield}

The data on Soybean yield (Table 3) indicated that the FLDs given a good impact on the farming community of Rudraprayag district as they were motivated by the new agricultural technologies adopted in the demonstrations.

Average soybean yield under front line demonstrations was observed as $15.94 \mathrm{q} / \mathrm{ha}$ which was higher by $30.96 \%$ over the prevailing farmers practice $(10.29 \mathrm{q} / \mathrm{ha})$.

The results clearly indicated that the yield of soybean could be increased over the yield obtained under farmer's practices by accelerating the adoption of recommended production technology for the concerned districts. Singh (2002), Dixit and Singh (2003), Singh et al., (2014) and Sharma et al., (2016) also found similar findings.

\section{Extension and technology gap}

The extension and technology gap are 3.77 $\mathrm{q} / \mathrm{ha}$ and $14.06 \mathrm{q} / \mathrm{ha}$ respectively during the period of demonstration emphasized the need to educate the farmers through various means for the adoption of improved agricultural production technologies to reverse this trend of wide extension gap. More and more use of latest production technologies with high yielding varieties will subsequently change this alarming trend of galloping extension gap.

The new agro-techniques will eventually lead to the farmers to replace old varieties with the new one. The technology gap observed may be attributed to the dissimilarity in the soil fertility status and weather conditions.

Hence, variety wise location specific recommendation appears to be necessary to minimize the technology gap for yield level in different situations. Singh et al., (2014) was also found similar findings. 


\section{Technology index}

The technology index indicates the feasibility of the evolved technology at the farmer's fields. The lower the value of technology index more is the feasibility of the technology.

The data (Table 3) showed that technology index value $47.39 \%$ was noticed in the year 2011 while in the year 2012 the value was $46.33 \%$, whereas the average value of technology index was recorded $46.86 \%$, it may be due to uneven and erratic rainfall and weather conditions of the area.

The results are corroborating with the findings of Hiremath and Nagaraju (2009), Dhaka et al., (2010), Singh et al., (2014) and Sagar and Chandra (2004).

\section{Economic analysis}

The higher cost of cultivation Rs. 11018 involved in FLDs as compared to Rs. 9630 under Farmers practice (Table 4). The FLDs plots fetched higher mean gross returns (Rs. 31883 /ha) and net returns (Rs. 20866/ha) with higher benefit: cost ratio (1.89) as compared to (gross returns Rs. 24350), (net returns Rs. 14720) and (benefit: cost ratio 1.53) with farmers practice. Hiremath and Nagaraju (2009), Sreelakshmi et al., (2012) and Joshi et al., (2014) also reported higher net returns and B: C ratio in the FLDs on improved technologies compared to the farmers practices and are at par with results of the present study which also resulted in higher net returns through FLDs on improved technologies.

Table.1 Details of package of practices followed in the frontline demonstrations (FLDs) vs farmers practice $(\mathrm{FP})$

\begin{tabular}{|l|c|c|}
\hline Inputs & FLDs & FP \\
\hline Soybean cultivar & PS 1092 & Local \\
\hline Seed rate & $75 \mathrm{Kg} / \mathrm{ha}$ & $125 \mathrm{~kg} / \mathrm{ha}$ \\
\hline Seed treatment & Bavistin @ $2.0 \mathrm{~g} / \mathrm{kg}$ seed & - \\
\hline FYM & $200 \mathrm{~kg} / \mathrm{Nali}$ & $200 \mathrm{~kg} / \mathrm{Nali}$ \\
\hline Weed management & $\begin{array}{c}\text { Two hand weeding, first at } 25 \text { days after sowing and } \\
\text { second } 45 \text { days after sowing }\end{array}$ & - \\
\hline
\end{tabular}

Table.2 Ranks for different constraints given by farmers

\begin{tabular}{|l|c|c|}
\hline Constraints & Percentage & Rank \\
\hline Improved Varieties of Soybean & 80 & I \\
\hline Low technical knowledge & 73 & II \\
\hline Insect & 67 & III \\
\hline Damage by wild animals & 63 & IV \\
\hline Use of higher seed rate & 30 & V \\
\hline Low soil fertility & 27 & VI \\
\hline Weed infestation & 25 & VII \\
\hline Diseases & 13 & VIII \\
\hline
\end{tabular}


Table.3 Yield performance of soybean under FLDs

\begin{tabular}{|c|c|c|c|c|c|c|c|c|}
\hline Year & $\begin{array}{c}\text { No. of } \\
\text { demo. }\end{array}$ & $\begin{array}{c}\text { Area } \\
\text { (ha) }\end{array}$ & \multicolumn{2}{|c|}{ Yield (q/ha) } & $\begin{array}{c}\text { \% yield } \\
\text { increase over } \\
\text { FP }\end{array}$ & $\begin{array}{c}\text { Extension gap } \\
(\mathbf{q} / \mathbf{h a})\end{array}$ & $\begin{array}{c}\text { Techo logy gap } \\
(\mathbf{q} / \mathbf{h a})\end{array}$ \\
\hline $\mathbf{2 0 1 1}$ & 30 & 0.60 & 15.78 & 12.15 & 29.92 & 3.63 & 14.22 \\
\hline $\mathbf{2 0 1 2}$ & 30 & 0.60 & 16.10 & 12.20 & 32.00 & 3.90 & 13.90 \\
\hline Mean & 30 & 0.60 & 15.94 & 12.18 & 30.96 & 3.77 & 46.33 \\
\hline
\end{tabular}

Table.4 Economics, additional cost and returns in Soybean under frontline demonstrations (FLDs) vs framers practice (FP)

\begin{tabular}{|c|c|c|c|c|c|c|c|c|c|c|}
\hline \multirow[t]{2}{*}{ Year } & \multicolumn{2}{|c|}{$\begin{array}{l}\text { Cost of cultivation } \\
\text { (Rs./ha) }\end{array}$} & \multicolumn{2}{|c|}{$\begin{array}{l}\text { Gross returns } \\
\text { (Rs./ha) }\end{array}$} & \multicolumn{2}{|c|}{ Net returns (Rs./ha) } & \multirow{2}{*}{$\begin{array}{l}\text { Additional } \\
\text { cost of } \\
\text { cultivation } \\
\text { (Rs./ha) in } \\
\text { FLD }\end{array}$} & \multirow{2}{*}{$\begin{array}{l}\text { Additional } \\
\text { returns (Rs./ha) } \\
\text { in } \\
\text { FLD }\end{array}$} & \multicolumn{2}{|c|}{ B: C Ratio } \\
\hline & FLD & $\mathrm{FP}$ & FLD & FP & FLD & $\mathrm{FP}$ & & & FLD & FP \\
\hline 2011 & 10960 & 9610 & 31567 & 24300 & 20607 & 14690 & 1350 & 7267 & 1.88 & 1.53 \\
\hline 2012 & 11075 & 9650 & 32200 & 24400 & 21125 & 14750 & 1425 & 7800 & 1.91 & 1.53 \\
\hline Mean & 11018 & 9630 & 31883 & 24350 & 20866 & 14720 & 1388 & 7533 & 1.89 & 1.53 \\
\hline
\end{tabular}

Table.5 Extent of farmers' satisfaction over performance of FLDs

\begin{tabular}{|l|c|c|}
\hline Satisfaction level & Number & Percent \\
\hline High & 40 & 67 \\
\hline Medium & 15 & 25 \\
\hline Low & 5 & 8 \\
\hline
\end{tabular}




\section{Additional cost of cultivation and returns}

Further, data (Table 4) revealed that the average additional cost of cultivation (Rs. 1388/ha) under integrated crop management demonstrations and has yielded additional net returns of Rs. 7533 / ha. The results suggest that higher profitability and economic viability of Soybean demonstrations under local agro-ecological situation.

\section{Farmer's satisfaction}

Client satisfaction index (CSI) presented in Table 5 observed that majority of the respondent farmers expressed high $(67 \%)$ and medium $(25 \%)$ level of satisfaction regarding the performance of FLDs, whereas, very few $(8 \%)$ of respondents expressed lower level of satisfaction. Majority of responding farmers under higher and medium level of satisfaction with respect to performance of demonstrated technology indicate stronger conviction, physical and mental involvement in the frontline demonstrations which in turn would lead to higher adoption. The results are corroborated with the results of Kumaran and Vijayaragavan (2005) and Dhaka et al., (2010).

Thus, it may be concluded that the yield and returns in soybean crop increased substantially with the improved production technologies. However, the yield level under FLDs was better than the farmer practice and performance of these varieties could be further improved by adopting recommended production technologies. So, there is need to disseminate the improved technologies among the farmers with effective extension methods like training and field demonstrations. The farmers should be encouraged to adopt the recommended agro-techniques for getting maximum returns in specific locations. Thus, it was clearly showed that the demonstration of soybean with full package was better to farmer's practices. The results indicated that the frontline demonstration has given a good impact on the farming community of the districts as they were motivated by the new agricultural technology applied in the FLD plots. Similar findings were reported by Kirar et al., (2006).

\section{Acknowledgement}

I am sincerely thankful to all the farmers on whose field frontline demonstration were conducted. The financial assistance provided by Indian Council for Agricultural Research, New Delhi and Zonal Project Directorate (ICAR) - Zone IV, Kanpur. The opinions expressed in this paper are the author's own and do not necessarily reflect the views of the donor or the authors' institution.

\section{References}

DAC, GOI, (2016). Agricultural statistics at a glance. 2016. http://agricoop.nic.in/ Agristatistics.htm).

Dhaka, B.L., Meena, B.S. and Suwalka, R.L. 2010. Popularization of improved maize production technology through frontline demonstrations in south-eastern Rajasthan. J. Agril. Sci. 1(1): 39-42.

Dhruw, K.S., Sengar, R.S. and Yadav, K.N. 2012. Level of knowledge and adoption about recommended maize production technology. Agril. Update 7(3\&4): 311315.

Dixit, S. N. and Singh, S. P. (2003). Evaluation of improved techniques on tomato and onion under frontline demonstration. Bharitiya Krishi Anusandhan Patrika, 18 (1 \& 2): 61-64

Dupare, B.D.; Billore, S.D. and Verma, S.K. (2012). An analytical study of seed scenario at farmers' level in major soybean growing states. Soybean Research, 10: 93-98 (2012). 
Hiremath, S.M. and Nagaraju, M.V. 2009. Evaluation of front line demonstration trials on onion in Haveri district of Karnataka. Karnataka J. Agril. Sci. 22(5): 1092-1093.

Joshi, N.S., Bariya, M.K. and Kunjadia, B.B. (2014). Yield gap analysis through front line demonstrations in rapeseed-mustard crop. International J. Scientific Res. Pub. 4(9): 1-3.

Kirar, B.S.; Narshine, R; Gupta, A. K. and Mukherjee, S.C. (2006). Demonstration: An effective tool for increasing the productivity of Urd. Ind. Res. J. of Ext. Edu., 6 (3): 47-48.

Kumaran, M. and Vijayaragavan, K. 2005. Farmers' satisfaction of agricultural extension services in an irrigation command area. Indian Journal of Extension Education, 41(3\&4): 8-12.

Meena B.L., Meena, R.P., Meena, R.R. and Bhim S. 2014. Popularization of improved maize production technology through frontline demonstrations in semi-arid zone IVA of Rajasthan. $J$. Appl. Nat. Sci. 6(2): 763-769.

Meena, D.S.; Ali, M.; Ram, Baldev and Tetarwal, J.P. (2012). Impact of improved technology on soybean productivity in South Eastern Rajasthan. Soybean Research, 10: 99-103 (2012).

Nagarajan, S. 1997. Perspectives on wheat demand and research needs. Wheatresearch needs beyond 2000 AD Proc.
Int. Group Meeting held at DWR, Karnal, India, 12-14 Aug. pp. 14-15.

Sagar, R.L. and Ganesh Chandra (2004). Frontline demonstration on sesame in West Bengal. Agril. Ext. Review, 16 (2): 7-10

Samui, S.K., Moitra, S., Ray, D.K., Mandal, A.K. and Saha, D. (2000). Evaluation of frontline demonstration on groundnut. $J$. of the Indian Society Costal Agril. Res., 18 (2): 180-183.

Sharma, V., Kumar, V., Sharma, S.C. and Singh, S. 2016. Productivity enhancement and popularization of improved production technologies in wheat through frontline demonstrations. Journal of Applied and Natural Science 8(1): 423- 428.

Singh, P.K. (2002). Impact of participatory planning on adoption of new technology through FLD Manage. Ext. Res. Review. July-Dec, 45-48

Singh, S.R.K., Mishra, A., Gautam, U.S., Dwivedi, A.P. and Chand, Prem (2014). Scouting technological vis-a-vis extension gaps in soybean production in Madhya Pradesh. Indian Res. J. Ext. Edu. 14 (2), May, 2014

Sreelakshmi, C.H., Sameer, K., C.V. and Shivani, D. (2012). Productivity enhancement of pigeon pea through improved production technology. Madras Agril. J. 99(4-6): 248-250.

\section{How to cite this article:}

Singh, S.B. 2018. Impact of Frontline Demonstrations on Yield of Soybean (Glycine max L. Merril) under Rainfed Conditions in Uttarakhand, India. Int.J.Curr.Microbiol.App.Sci. 7(05): 986-992. doi: https://doi.org/10.20546/ijcmas.2018.705.122 